\title{
'n Sosiologiese perspektief op die literêre komposisie van die Sinaikompleks (Eksodus 19-34)
}

\section{A P van Tonder \& J P Oberholzer Universiteil van Prctoria}

\begin{abstract}
A sociological perspective on the literary composition of the Sinai complex (Exodus 19-34)

The elaborate account of Exodus 19-34 is rooted in a pre-exilic Mountain of God tradition which arose primarily from the imagery of divine presence that is assumed in the description of theophany. Deuteronomistic and priestly redactors both significantly expanded this pre-exilic tradition by anchoring their legislation in this event. The underlying motif of the final redaction of the entire Sinai complex reflects rivalry between priestly houses during the Persian period, one tracing its lineage to Moses (Levites) and the other its lineage to Aaron (Zadokites).
\end{abstract}

\section{INLEIDING}

Navorsing oor die afgelope vyftig jaar het aangetoon dat die Sinaikompleks uit 'n komposisionele gelaagdheid van tradisies bestaan, waarin meer as een ontwikkelingstadium waargeneem kan word. Die atomistiese analise van die kritiese benadering het dikwels tot 'n anomalie van onopgeloste probleme gelei. Die klem het so sterk op die sinoptiese vraagstuk van bronnetradisies geval, dat die geïmpliseerde boodskap van die teks verskraal is en dit tot alternatiewe navorsingbenaderings gelei het. Die huidige tendens in die Pentateugnavorsing is om 'n herwaardering van die redaktor se rol daarin te makk (Rendtorff 1977; Dozeman 1989a; Blum 1990).

Die begrip 'Sinaikompleks' vereis ook duideliker omskrywing. In geheel strek die Sinaikompleks van Eksodus 19:1 tot Numeri 10:10. Die fokus van hierdie studie het egter op die komposisionele verband van Eksodus 19-34 betrekking, waarin God se openbaring en wetsafkondiging op Sinai beskryf word.

* Voorgelê en aanvaar as deel van die vereistes vir die MDiv-graad, Fakulteit Teologic (Afd A), Universiteit van Pretoria, onder leiding van prof dr J P Oberholzer. Finansiële bystand van die Sentrum vir Wetenskapsontwikkeling word hiermee erken. Standpunte wat hier uitgespreek word, is dié van die outeur en nie noodwendig die van die SWO nie. 
Onderliggend aan die Sinaikompleks is bepaalde ideologiese invloede wat die kontemporêre tyd van die redaktor reflekteer. Die doel van hierdie ondersoek is om, aan die hand van 'n sosiologiese epistemologie, perspektief op die ideologiese invloed van Israel se godsdiensontwikkeling te probeer werp. Besondere aandag sal geskenk word aan (a) die literêre tradisies wat deur die redaktor met die finale komposisie gebruik is, (b) die sosio-historiese agtergrond van sowel die redaktor as sy teikengroep, en (c) die teologiese boodskap van die redaktor. Hiervoor moet die ideologiese veranderinge, sentimente en situasie in Palestina ook in ag geneem word.

Eerstens sal 'n analise van die komposisionele samestelling van die literêre tradisies van die Sinaikompleks gedoen word om die groeiproses daarvan in sy tradisiegeskiedenis na te gaan. Die eindredaktor(s) het van bestaande tradisies gebruik gemaak om die finale produk van die Sinaikompleks te skep. Hierdie tradisies ontsluit iets van die literêre en teologiese agtergrond van die redaktor(s). Sy denke is op die teologiese inhoud van ouer tradisies gebou. Hiermee is groter outoriteit aan sy boodskap gegee, omdat dit op vroeëre openbaringe van Jahwe gegrond is. Sodoende is ' $n$ brug tussen die verlede en die hede gebou.

In die tweede plek sal 'n diakroniese studie van die literêre groeiproses onderneem word wat komplementêr op die sinkroniese vlak inwerk. 'n Ondersoek na die redaktor(s) se hantering van hierdie onderliggende tradisies, kan lig op die bedoeling van sy werk werp. Hierin dien die redaktor(s) se woordgebruik en woordspelings as belangrike sosio-kulturele en -historiese leidrade om die wêreld van Israel se politieke en teologiese stryd oop te sluit. Die religieuse, sosiale, politieke en ekonomiese faktore wat die redaktor(s) beïnvloed het, sal sy sosiale konteks makliker kan bepaal.

Derdens sal die redaktor(s) se teologiese boodskap in 'n gegewe konteks ondersoek word. Hy het sy boodskap kontemporêr vir die toekoms geskryf. Derhalwe sal sy woorde perspektief op Israel se kontemporêre teologiese posisie bied. 'n Simbiotiese verhouding tussen die komposisionele tradisies, die sosio-historiese agtergrond daarvan en die teologiese boodskap van die redaktor kan dieper insig in die sosiale konteks van die redaktor bied.

\section{KOMPOSISIONELE ANALISE VAN DIE LITERèRE TRADISIES}

Die komposisionele samestelling van die Sinaikompleks word deur veelvuldige herhalings en diskrepansies gekenmerk. Geleerdes was dit vroeg reeds eens dat dit op die resultaat van 'n redaksionele proses dui waarin bestaande bronne met nuwe tradisies uitgebrei is. Cross (1973:291-325) se standpunt dat P nie 'n onafhanklike bron is nie, maar ' $n$ redaksie van ouer bronne, het besondere implikasie vir die tradisie- 
historiese en teologiese interpretasies van Eksodus 19-34. Hoewel Eksodus 19-24 en Eksodus 32-34 as twee afsonderlike komposisionele eenhede in Eksodus staan (Chirichigno 1987:457-479; Davis 1982:71-87), bestaan sterk aanduiding dat die hand van dieselfde literêre redaktor(s) in beide dele voorkom. 'n Analise van die redaksionele samestelling van Eksodus 19-34 dui daarop dat dit 'n ontwikkeling van drie tradisiestrata aandui, te wete: 'n pre-deuteronomistiese Berg-van-God-tradisie, wat afsonderlik deur 'n deuteronomistiese Horebtradisie en 'n priesterlike Sinaitradisie uitgebrei is.

\subsection{Die pre-deuteronomistiese tradisie}

Resente navorsing het aangetoon dat die Sinaikompleks op 'n pre-deuteronomistiese tradisie ten grondslag gelê is wat oor 'n lang tydperk heen redaksioneel uitgebrei is (Dozeman 1989a; Phillips 1984a:39-52; 1984b:282-294). Dit word as 'n Berg-vanGod-tradisie getipeer wat Elohim se verskyning op 'n naamlose kosmiese berg beskryf en word aan die werk van een skrywer toegeskryf. Die ouderdom van die

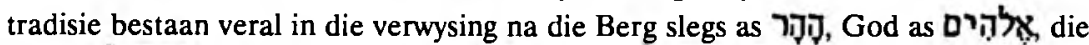

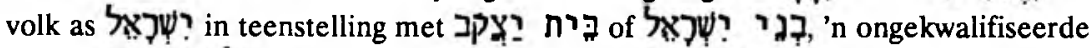

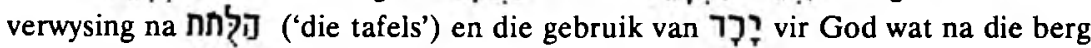
'neerdaal' of Moses wat daarvandaan 'afklim'.

Die Berg-van-God-tradisie vertoon 'n konsentriese ringskomposisie wat in twee parallelle dele ' $n$ samehangende verband met mekaar vorm. Die eerste deel beskryf (a) Israel se aankoms by 'n naamlose kosmiese berg (Eks 19:2b-3a). Noth (1962: 157) beskou dit as die oorspronklike inleiding op die Berg-van-God-tradisie. (b) Hierna volg 'n reinigingsverhaal van die volk (Eks 19:10b-11a), 'n afgrensing van die berg (Eks 12a, 13b-15a) en die teofaniebeskrywing (Eks 19:16a- 17). Die afgrensing van die berg aksentueer die sakrale karakter daarvan. Sodoende word 'n vertikale hiërargie geskep: God word op die kruin van die berg voorgestel, die volk aan die voet daar-van en Moses wat tussenin beweeg. Die taalgebruik vir die teofanie, is meer beskry-wend van 'n Kanaănitiese stormteofanie as vir 'n vulkaniese uitbarsting (Cross 1988:60). (c) Die eerste deel word met 'n offerritueel deur die 'jongmanne van Israel' aan die voet van die berg afgesluit (Eks 24:4a-5a).

Hierna volg 'n verdelingsas tussen die twee dele waarin (d) Moses opdrag ontvang om teen die berg op te klim (Eks 24:12ab, 13b, 15, 18) en die kliptafels van God te ontvang (Eks 31:18a, 18b). Die tweede deel beskryf (c') Israel se verbondsverbreking en ongehoorsaamheid (Eks 32:1a, 4a), die tafels van God (Eks 32:15a, 16) en Moses se vernietiging daarvan (Eks 32:19). Hierna volg die beskrywing van (b') 'n nuwe teofanie op die berg (Eks 34:2a-3, 5a), wat weer afgesluit word (a') met 'n religieuse handeling van Moses (Eks 34:8), 'n verbod op die maak van gegote 
gode (Eks 34:17) en 'n opmerking dat God dit op die tafels geskryf het (Eks 34:28c) en dat dit as vereiste vir die herstel van God se verhouding met Israel dien (Eks $34: 17-18 \mathrm{ab}, 19-20,22,26 \mathrm{~b} ; 28 \mathrm{c})$.

\subsection{Die deuteronomistiese tradisie}

Deuteronomistiese redaktor(s) het die volgorde (Perlitt 1969:77-102) van die Bergvan-God-tradisie behou (Dozeman 1989a:37-86) en dit met hulle eie interpretasie uitgebrei. Die teksinhoud vertoon kenmerkende deuteronomistiese fraseologie waarin sowel Jahwe se rede as Israel se antwoord as deurlopende motief geaksentueer word (Nicholson 1982:74-86). Die herhaling van die woordmotiewe

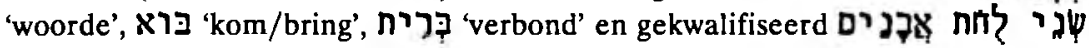
'twee kliptafels' speel hierin veral 'n groot rol. Die ontwikkeling van 'n tema en teologiese perspektief op die teenwoordigheid-afwesigheid-teenwoordigheid van Jahwe (Durham 1978:446), Moses se rol as Sy verteenwoordiger en die tema van 'sonde en vergifnis' stem ooreen met 'n deuteronomistiese invloed. Laasgenoemde motief kom ook in die sondevalverhaal in Genesis 3 en die sondvloedverhaal in Genesis 6-9 voor (Moberly 1983:91-92).

In die eerste siklus is (a) Israel se aankoms by die Berg met 'n verbondsvoorstel uitgebrei (Eks 19:3b-5b, 6b-8a). Die verband tussen die Berg-van-God en die deuteronomistiese verbondsvoorstel word veral deur Moses se aksie gelê. Anders as by die Berg-van-God- tradisie daal hy nie meer na die volk toe af (ר) nie, maar bring (X) ב hy die woorde van Jahwe na hulle toe. So is nuwe betekenis ook aan Moses se rol gegee, wat van 'n middelaarsfunksie tot 'n profetiese leraarsrol ontwikkel het, deur dit 'n voorvereiste vir die teofanie te maak. Die formule, 'so moet jy vir...sê', versterk sy profetiese rol. (b) Dit word gevolg deur 'n betekenisvolle interpretasie van die teofanie (Eks 19:8b-9a, 19; 20:18-20), wat as basis vir die openbaring van die dekaloog (Dozeman 1989a:5-47) in Eksodus 20:1-17 gedien het. Eerstens beklemtoon dit God se teenwoordigheid op die berg as voorvereiste vir 'n Goddelike verskyning (בר); daarna het die teofanie ten doel dat die volk dit as 'n Godspraak moes hoor (ט) $\boldsymbol{W}^{\prime}$; derdens wil dit Moses as gesaghebbende verteenwoordiger van God bevestig sodat hy by die volk vertroue (TDN) kan inboesem (Eks 20:18-20). (c) In die derde episode word die Berg-van-God-tradisie betekenisvol met die Verbondsboek (Eks 20:23-23:33) en 'n verbondsluitingseremonie (Eks 24:3-4a,7) uitgebrei. Die strukturele bou hiervan is in ' $n$ deurlopende gespreksraamwerk tussen Jahwe-(Moses)-Israel geplaas.

Die vierde episode vind aansluiting by die Berg-van-God-tradisie in Moses se opdrag om die berg te bestyg en brei dit uit met (d) 'n kwalifisering van die inhoud van die kliptafels (Eks 24:12b) en 'n reëling ten opsigte van die hantering van regsake in sy afwesigheid (Eks 24:14). 
Die tweede deel brei (c') Israel se verbondsverbreking uit met Aäron se aandeel in die verbondsontrou (Eks 32:1a-4a, 5, 7-14, 20-24, 25-29, 30-35; 33:1-6, 12-17). Dit word gevolg met (b') 'n nuwe openbaring (Eks 34:1, 4a, 4b, 5b-7) en (a') die sluiting van 'n verbond (Eks 34:9-10, 11-16) en aanvullende wetlike materiaal (Eks 34:18-27, 28b).

Die deuteronomistiese redaksie plaas 'n geweldige hoë premie op die verbond en om Israel op die gevaar van sinkretisme met die Kanaänitiese godsdiens te wys. Vermeylen (1985:1-23) onderskei vier deuteronomistiese redaktors tussen 585-520 v $\mathrm{C}$, wat tot hierdie interpretasie en verdere uitbreiding van die Berg-van-Godtradisie bygedra het, en verdeel die werksaamhede van die deuteronomistiese redaktors soos volg: Dtr585 v $C$ (Eks 20:2-6; 24:3b; 32:32:7-10a, 11-12, 14-16, 19b20, 30-32, 34; 33:2-4, 15-17; 34:6-7, 28b, 29); Dtr575 v $C$ (Eks 20:22-23:33; 24:3-5, 8, 12-13); Dtr560 v $C$ (Eks 32:20, 32b-33, 35ab; 33:1, 5-6, 12b-14; 34:8-10a, 11-16, 18b, 21, 23-26a); Dtr525 v C (Eks 19:3b-8; 24:6-7, 13, 14-15a; 32:1-6, 10b, 13, 17-18, 25-29, $35 ; 34: 10 a, 13)$.

\subsection{Die priesterlike tradisie}

Soos die deuteronomistiese redaksie volg die priesterlike redaksie ook die skema van die Berg-van-God-tradisie en brei dit met sy eie interpretasies uit. Volgens Labuschagne (1982:268-296; 1984a:91-95; 1984b:407-413) vertoon die Godsredes 'n konsekwente, samehangende en fyn uitgewerkte skema. Karakteristieke motiewe

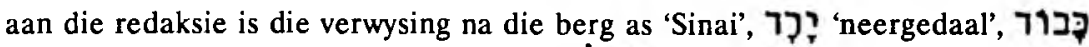

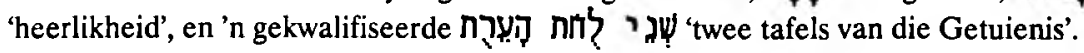

In die eerste deel is (a) die inleiding (Eks 19:1-2a) spesifiek oor die tyd en plek van die teofanie. Die Berg word in die Sinaiwoestyn gelokaliseer, met Israel se aankoms presies drie maande ná die uittog. Booij (1984:17) skryf: 'In this introduction רד] evokes a memory of the mountain of God in Exodus 18:5 and of Horeb in Exodus 17:6'. Dit brei die deuteronomistiese verbondsvoorstel (Eks 19:3b-5b) uit met 'n belofte om Jahwe se heilige en eksklusiewe eiendom te wees (Eks 19:5b-6a).

Die nuwe agtergrond en heiligingsmotief dien in die tweede episode as basis vir die verdere ontwikkeling van die (b) teofanie (Eks 19:11b, 12a-13, 15b-16a, 18), 'n gepaardgaande reinigingsverhaal (Eks 19:20-25) en opdrag aan Moses om die berg te bestyg (Eks 24:1-2). In teenstelling met die ouditiewe ervaring van die teofanie in die deuteronomistiese redaksie, gee die priesterlike redaksie visueel uitdrukking aan die verskyning van Jahwe. Hy daal in die visuele vorm van vuur op die berg neer, terwyl die berg rook (Eks 19:16a, 18). In Eksodus 19:20-25 en 24:1b-2 word ook weggedoen met die deuteronomistiese leraarsvoorstelling van Moses ten gunste van 'n priesterlike middelaarsrol (Noth 1972:186; Schmitt 1983:84). 
Die eerste deel sluit af met (c) 'n offerritueel (Eks 24:5a-6, 8, ) en visuele ervaring van Jahwe wat, in teenstelling met die deuteronomistiese verbondseremonie, as 'n heiligingseremonie voorgestel word. Die offerritueel deur die 'jongmanne van Israel' (Eks 24:5a) word met 'n bloedritueel (Eks 24:6, 8) vervang, sodat uitdrukking aan 'n versoening met Jahwe verleen kon word (Hendel 1989:386-389).

In die middelstuk (d) word die Berg-van-God-tradisie met 'n tweede en onafhanklike Kebôd Jahwe-teofanie (Eks 24:9-11, 13a, 16-17) en 'n berig van die oorhandiging van die 'tafels van die Getuienis' (Eks 31:18) uitgebrei. Enersyds beklemtoon dit Jahwe se visuele sigbaarheid en Kabôd en andersyds lê dit 'n funksionele band met die priesterlike wette in Eksodus 25-31. Die tradisie in Eksodus 24:9-11 is in die verlede dikwels of as 'n verbondsmaal tussen Jahwe en Israel (Rowley 1967:52-53), 6f as religieuse diens (Dozeman 1989:113-115) geïnterpreteer. Dozeman volg hier Nicholson (1974:77-97) se aanvanklike standpunt sonder in agneming van sy regstelling hiervan (kyk Nicholson 1976:148-150). Die probleem met beide interpretasies is egter dat dit die konteks van 'n enkele uitdrukking (aan die einde daarvan) afhanklik maak, en die hele tradisie daarvolgens wil interpreteer. Die strukturele samestelling van die tradisie dien as belangrike sleutel vir die interpretasie daarvan. Dit vertoon 'n chiastiese struktuur in Eksodus 24:10-11 waarmee vertel word dat Moses en sy gevolg Jahwe 'gesien' het, sonder dat God 'sy hand na hulle uitgestrek het' (Eks 24:11a) en hulle volgens verwagting sou sterf (Eks 20:19). Hulle het God gesien, maar bly leef. Hierna volg die frase, 'hulle het geeët en gedrink'. Die uitdrukking word ook in Eksodus 32:6 en Eksodus 34:28a gebruik, terwyl dit ook elders in die Ou Testament (1 Kon 4:20, Jer 22:15, Pred 5:16, Am 7:12) voorkom met die betekenis om 'voorspoedig te lewe', 'die lewe te geniet' of 'om te lewe' (Nicholson 1976:148-150). Die chiastiese parallel lees dan soos volg:

a hulle het die God van Israel gesien (Eks 24:10a);

b wat hulle onder 'Sy voete' gesien het (Eks 24:10b);

b' Hy het nie 'sy hand' na hulle uitgesteek nie (Eks 24:11a);

a' hulle het Jahwe gesien en geeët en gedrink (bly leef) (Eks 24:11b).

Die tradisie het dus betrekking op die ervaring van Israel se afvaardiging op die berg van God. Nadat hulle die berg bestyg het, het hulle God in Sy woonplek gesien, maar ongedeerd gebly. Die tradisie blyk 'n baie ou pre-Deuteronomistiese teofanietradisie te wees wat deur die priesterlike redaksie aangepas is. Nicholson (1974:95) beskou dit as 'the tradition par excellence in the Old Testament'. Volgens hom verskil dit van ander teofanietradisies in die Sinaikompleks (Nicholson 1975:979) daarin dat: (a) dit nie 'n teofanie met donderslae, weerlig en bewing of 'n berg 
wat met 'n wolk, rook en vuur omhul word, ken nie. (b) Die noodlottige gevolg wan-neer God gesien word, word wel geïmpliseer (Eks 24:11a), maar dit beskryf nogtans dat Moses en sy gevolg Hom gesien het. Hierteenoor benadruk ander teofanietradisies in die Sinaikompleks die verborgenheid van God. (c) Moses se rol word drasties kleiner voorgestel vergeleke met sy dominante rol in ander teofanietradisies. Noth (1972:162) is van mening dat Moses nie oorspronklik tot die tradisie behoort het nie, maar 'n latere redaksionele byvoeging is.

Dit is nie maklik om die godsdiens-historiese agtergrond van Eksodus 24:9-11 vas te stel nie. Beyerlin (1961) bring dit, in navolging van Noth, met 'n sogenaamde amfiktionie van die pre-monargale tyd in verband. Zenger (1971:164) kwalifiseer die tradisie as ' $n$ Jahwistiese redaksie van $J$ of $E$ gedurende die tyd van Hiskia, ná die val van die Noordelike ryk in 721 v C, '...zur Verherrlichung des Zion...' ter steun vir Hiskia se reformasieproses. Die lengte van die tradisie lewer 'n wesenlike probleem om die tradisie sinvol met 'n spesifieke agtergrond, oorsprong of doel te verbind. Dit bring mee dat enige konklusies hieroor hoogstens hipoteties van aard kan wees. Belangrik is dat hier 'n tradisie bestaan wat 'n ervaring van Israel se voorsate op die berg van God wil beskryf en wat besondere betekenis vir die perikoop het.

Die tweede deel beskryf (c') die verbondsverbreking (Eks 32:6), 'n verwysing na 'die twee tafels van die Getuienis' (Eks 32:15, 17-18) en Moses se waarneming van die verbondsontrou (Eks 32:17-18). Dit vind voortsetting in (b') 'n nuwe openbaring van 'n Tent van Samekoms-tradisie (Eks 33:7-11), 'n Kebôd-teofanie (Eks 33:18- 23) en 'n reinigingsverhaal en opdrag om op die Sinaiberg te klim (Eks 34:2a, 4a, 28ab). Die tradisie word afgesluit met (a'), Moses se blinkende gesig (Eks 34:29-35), wat as uitbreiding volg op die Berg-van-God-tradisie se vereiste vir die herstel van God se verhouding met sy volk.

\section{DIE VERHOUDING TUSSEN TRADISIE EN REALITEIT}

Mense se begrip van die wêreld staan onder sterk invloed van hulle omgewing, sosio-kulturele tradisies en interpretasie daarvan. Dit geld ook die groeiproses van die Sinaikompleks. Die ideologiese persepsies van sy kontemporêre tyd het 'n groot invloed op die redaktor se tradisiekeuse en redaksionele kommentaar. Dit spreek vanself dat die redaktor gemeenskaplike kennis met sy tydgenote in institu-sionele patrone sou legitimeer ten einde 'n groep in staat te stel om: (a) hul lewensbeskouing te behou, (b) verskillende dele van sy wêreldbeskouing te integreer en (c) te verklaar waarom dinge gedoen word soos dit gedoen is. As deel van 'n sosialiseringsproses is hierdie realiteitskonstruksie deur die ouers aan hul kinders oorgedra om hulle in 'n groep se realiteitsbegrip te laat deel. Hierin het simbole 'n 
belangrike rol gespeel. Die kosmiese bergsimboliek in die Sinaikompleks vereis dat die sosiale konteks wat daaraan gestalte gegee het, ondersoek moet word aangesien simbole institusioneel en sosiologies van aard is.

\subsection{Die konstruksie in die Berg-van-God-tradisie}

In die Berg-van-God-tradisie is grootliks van 'n ontmitologisering van ou mites wat in 'n nuwe konteks verhistoriseer is, gebruik gemaak om 'n realiteitsbegrip te skep. God se teenwoordigheid in die kultus is met 'n metaforiese funksie van die berg voorgestel. Die berg het 'n statiese en permanente teenwoordigheid van God gesimboliseer. Besondere klem word op die noue verband tussen die berg en Elohim gelê. Die indruk word gewek dat Elohim reeds, met Israel se aankoms (Eks 19:2b-3), op die berg was en dit Sy woonplek was. Dit word met die daaropvolgende teofaniebeskrywing (Eks 19:16-17) gesteun, deurdat geen beskrywing van 'n goddelike nadering tot die berg gegee word nie en God se teenwoordigheid ten tye van die offerritueel (Eks 24:4a-5) vooronderstel word. Hierdie permanente teenwoordigheid van God is deur sowel visuele as ouditiewe motiewe in die voorstelling van 'n donderstorm en trompetgeskal aan Israel bekend gemaak.

Die stormteofanie reflekteer 'n ou Mesopotamiese en Wes-Semitiese mitologie wat die berg (of tempels en hoogtes as verteenwoordigend daarvan) as die woonplek van 'n god voorstel. Die woonplek van Baäl was ook'n kosmiese berg. Die tempel van Marduk was in Babilonië op grondvlak eerder as op 'n berg geleë en het as halfweghuis vir die gode gedien in hulle reis tussen die hemel en apsû as ideale ontmoetings-plek met mense (Talmon 1978:436). Volgens mitologiese voorstelling het die berg 'n spesifieke heilige karakter gehad. In die Berg-van-God-tradisie is hierdie interpretasie verander. Die berg was nie meer op sigself heilig nie, maar het in assosiasie met die God van Israel 'n sakrale karakter ontvang en sodoende metafo-ries uitdrukking aan die kultiese teenwoordigheid van God gegee. Die resultaat hiervan was dat die berg 'n strukturele rol in die definiëring van die karakters gespeel het: Jahwe is bo-op die berg voorgestel, met Israel aan die voet daarvan en Moses wat tussenin beweeg.

Hierdie voorstelling korrespondeer met die pre-eksiliese Sion-Sebaot teologie wat sy sterkste uitdrukking in die assosiasie van Jerusalem met sy heilige Sionberg (Talmon 1978:436) en Jahwe se woonplek in die tempel daarvan, vind. Mettinger (1982:28) beskou $ב W$ as 'the key expression recurring in significant contexts to express the presence of God in the Temple and on Zion'. Soms is die berg ook as alternatief vir Jerusalem of die tempel daarvan gebruik (Ps 48:3; 99:9; Jes 24:23; 52:7). In die Sion-Sebaot-teologie het die tempel 'n unifiërende funksie tussen die hemel en aarde vervul wat sy hoogste uitdrukking in 'n anikoniese en antropomor- 
fiese kultiese simboliek gevind. Hierin word Jahwe as 'n God voorgestel wat onsigbaar op sy troon sit en universeel regeer (Ps 10:16; 48; 74:12; 93:1; 95:3; 96:10; 99:1, $5,9)$.

Die Sion-Sebaot-teologie se begrip van die koms van God het in teofanietradisies neerslag gevind (Ps 18:11). In die pre-eksiliese tyd het tempelteoloë die koninklikheid van God met die 'koms van God' laat saamsmelt. Hierdie assosiasie is 'n kenmerkende teologiese verwagting wat uit die konteks van die laat monargale tyd spruit waarin (a) 'n versekering van God se teenwoordigheid vereis word en (b) die redaksie 'n anti-Kanaänitiese polemiek teen religieuse sinkretisme voer. In die polemiese stryd hierteen maak die redaksie gebruik van Jerobeam I (922-907 v C) se religieuse beleid en oprigting van die kalf in Dan en Bet-El (1 Kon 12:25-33). Die verbod op die maak van gegote gode (Eks 34:17) het pertinent betrekking hierop. Mettinger (1982:37) verbind die tradisie met die Assiriese bedreiging van Jerusalem in 701 v C. Daar kan volstaan word daarmee dat dit 'n konteks reflekteer wat 'n krisis wou besweer en die versekering van Jahwe se teenwoordigheid en koms wou gee.

\subsection{Die konstruksie in die Horebtradisie}

Hoewel Eksodus 19-34, met uitsondering van Eksodus 33:6, nie eksplisiet na Horeb verwys nie, korrespondeer die bergtradisie goed met die ooreenstemmende tradisie in die boek Deuteronomium. Volgens Deuteronomium was Horeb die plek waar (a) Jahwe in 'n teofanie van vuur verskyn het, die dekaloog afgekondig en 'n verbond met Israel gesluit het (Deut 4:10, 15; 5:2; 28:69); (b) die volk voor God verskyn het om sy stem te hoor (Deut 4:10) en (c) Moses as profeet verorden is (Deut 18:16). Die feit dat die bergtradisie met 'n deuteronomistiese Horebtradisie uitgebrei is, beteken dat 'n nuwe inhoud daaraan verleen is. Die deuteronomistiese redaksie het van twee metodes gebruik gemaak om 'n nuwe realiteitsbegrip te skep. Eerstens is Israel se vroeëre belewing as realiteit gelegitimeer: (a) Jahwe se stem is gehoor, en $\mathrm{Hy}$ is ook as 'n persoon en krag ervaar; (b) vertroue in afgode is veroordeel en as fabrikate van mensehande afgemaak wat (c) vernietigbaar is en nie verlossing kan bied nie; daarenteen word beklemtoon dat Jahwe Israel uit Egipte gelei het.

Tweedens is Israel se nasionale geskiedenis kerugınaties oorvertel (Van Zyl 1992:264-271) deur (a) die uittog uit Egipte (Eks 19:4; 32:1, 4, 7-8, 11-12, 23; 33:1a) en (b) Jahwe se aartsvaderbelofte vir 'n nuwe land in herinnering te roep (Eks $32: 13 ; 33: 1 b-3$ ). Die nomadiese stammestruktuur was 'n uitgediende realiteit vir die deuteronomis. Vanuit 'n eksiliese konteks is 'n tipiese nomadiese droom van 'n 'beloofde land' aangegryp en oor tradisies heen tot 'n realiteit herskep. So is die 
grondslag vir 'n nuwe nasionale bewussyn gelê (Robinson 1982:558). Die formule in Eksodus 33:1-3 was 'n motiverende faktor in sy ywer om 'n eie land vir die Israeliete te verkry. Hiermee is 'n realiteitsbegrip geskep waarin die Israeliete se huidige belewing in ooreenstemming met hul verlede gebring is.

Die metaforiese interpretasie van God se verhouding met die berg in die Bergvan-God-tradisie, is tot 'n metonimie ontwikkel. Die berg funksioneer nie meer as woonplek van God nie, maar ontwikkel nou tot 'n ontmoetingsplek tussen God in die hemel en die volk op die aarde. Die teofanie gee uitdrukking aan Jahwe se rede, wat in die dekaloog as die digheid ontwikkel van 'n visuele ervaring tot die ouditiewe motief van 'n donderstorm wat as 'stem' van God 'gesien' is.

Die implikasie hiervan is dat Jahwe se Goddelike teenwoordigheid nie meer tot slegs 'n spesifieke kultiese sentrum beperk is nie, maar dat $\mathrm{Hy}$ oral waar die deuteronomistiese wet gesaghebbend verkondig is, teenwoordig was. Vir die deuteronomistiese redaksie kon dit slegs dàar geskied waar die verbondsark was, naamlik by Horeb. In aansluiting hierby is Moses metafories as 'n kultiese leier geïdealiseer. As leraar van die wet was sy rol verteenwoordigend van die teenwoordigheid van Jahwe.

Dit is duidelik dat die deuteronomistiese redaksie 'n spesifieke religieuse realiteitsbegrip wou skep wat polemies op die Sion-Sebaot teologie ontwikkel. Hierdie realiteitsbegrip is op die Horebtradisie oorgedra en as realiteitsperspektief van Jahwe gelegitimeer.

\subsection{Die konstruksie in die Sinaitradisie}

Die identifisering van Sinai met die teofanie en verskyning van Kebôd Jahwe, het 'n belangrike rol in die realiteitskonstruksie van die priesterlike redaksie gespeel. Dit het veral implikasie vir die priesterlike wetgewing. Die priesterlike redaksie het twee ou pre-eksiliese teofanietradisies, 'n 'Grens-in-die-Suide-' en ' $n$ 'Tent-vanSamekoms-tradisie' (Dozeman 1989a:122-126, 134), geneem en met die Berg-vanGod verbind. Dit het tot 'n nuanseverandering gelei. Sinai, wat aanvanklik as 'n woestynstreek in die 'Grens in die Suide-tradisie' bekend was, se redaksionele verbintenis met die Berg-van-God het daartoe gelei dat die kosmiese naamlose berg wat deur Moses bestyg is, eksplisiet as die Sinaiberg geïnterpreteer is (Dozeman 1989a:121-126). Pogings om die historiese Sinai met 'n noord-Midianitiese gebied (Cross 1989:46-64) of Suid-Edomitiese woestyn te verbind, het tot onbevredigende hipoteses gelei (Cohen 1983:16-29). Post-eksiliese literatuur verwys drie keer eksklusief na Sinai as 'n berg. In Esra se gebed tydens die verbondshernuwing (Neh 9:13-14) word na die Sinaiberg as plek van die wetgewing verwys. Sirag 48:7 verwys 
na Sinai en Horeb gemeenskaplik, en in II Esra 3:17-19 is dit die plek waar Jahwe Hom, ná die uittog uit Egipte, aan die nageslag van Jakob openbaar het. Dit dui daarop dat die Sinaiberg, gedurende die post-eksiliese tyd, 'n belangrike rol as plek vir die teofanie in die heilsgeskiedenis van Israel gespeel het.

Hiermee het die Sinaiberg 'n komposisionele funksie ontvang deurdat dit 'n konteks vir die priesterlike wetgewing geskep het: (a) as 'berg van die teofanie' (Eks 19:11, 18, 20, 23) het Sinai die openbaringsplek vir die Kebôd Jahwe geword. Kabôd word in konjunksie met Sinai (Eks 24:16-17) en in die kultus met die tabernakel (Eks 29:43) en die heiligdom (Eks 40:34-35) gebruik. (b) Verder dien dit ook as ankerpunt vir die priesterlike wetgewing in Eksodus 25-31 (Eks 24:16; 31:18); en (c) verleen dit konteks aan die priesterlike wetgewing in Eksodus 35 tot Numeri 10:10 (Eks 34:2, 29, 32) as 'n sogenamde 'berg van die verbondshernuwing'.

Die Kebôd Jahwe konsep het in sowel die Wes-Semitiese godsdiens as die Jerusalemkultus 'n voorgeskiedenis. Enersyds is dit met die teofaniekonsep verbind, en andersyds met die koningskap van God. In die Wes-Semitiese begrip was kabôd tot die 'hemelse gebied beperk'. Die priesterlike redaksie verbreed die reikwydte van Kebôd Jahwe tot 'n ruimtelike grootheid (Utzschneider 1988:49, 102) waarin God self teenwoordig is. Die priesterlike redaksie kwalifiseer God se verhouding met die berg metonimies, sodat dit nie meer as woonplek van God dien nie, maar in Sinai tot 'n halfwegpunt ontwikkel. God daal vanuit sy hemelse tempel (in vuur) hierheen neer om by die godsdienstige gemeenskap te wees. Die fokus verskuif terug na 'n visuele teofanie. Die vuur op die kruin van die berg kontrasteer die ouditiewe donderweer in die deuteronomistiese teofanie en ontwikkel in 'n sakramentele Kebôd Jahwe-teofanie (Eks 24:15b-18a). Hiermee word die Sion-Sebaot-teologie met 'n post-eksiliese Kebôd-teologie vervang (De Vaux 1973:272). Utzschneider (1988:51) skryf: 'Against this, the kabod theology may in principle be regarded as a restatement of the Zion-Sabaoth theology, since according to the kabod theology it is God who dwells in his sanctuary.'

Die kabôd-teofanie is baie gunstig teenoor 'n ou pre-monargale 'Tent van Samekomstradisie' (Eks 33:7-11; Num 11:14-17, 24-30; 12) en ontleen selfs sommige terminologie daaraan (Mettinger 1982:81-83). Dit is veral opmerklik in die redaksie se karakterisering van (a) die wolk as stramien vir die kabôd in Eksodus 24:16, 18 (asook Eks 16:10; 40:34-38); (b) die begrip en (c) die verskyning van die kabôd voor die ingang daarvan (Eks 25:22; 29:42-43; 30:6, 36). Hierbenewens reflekteer die kabôd-teofanie ook 'n tabernakelteologie wat met die Jerusalemse tempelteologie van die monargale tyd ooreenstem en terselfdertyd met Babiloniese simboliek korrespondeer. Die 'sien van God' (Eks 24:9-11) ontwikkel 'n kosmiese 
bergbeeld in assosiasie met die tempel. Die libnat hassapîr toon 'n verband met die lapis lazuli in die spits van die Babiloniese tempeltoring waar die god sou woon. Sodoende het die leiers van Israel 'n direkte visie van God op Sy troon van saffiersteen in die hemel gehad (Childs 1974:507; Dozeman 1989a:114). Die uitdrukking kom ook voor in Esegiël 1:26, Eksodus 28:18, Job 28:6, 16 en Jesaja 54:11.

Die tent dien as funksionele blyplek vir Jahwe wanneer Hy tussen sy volk wou wees (Eks 25:8; 29:42-46). Die tabernakelteologie (Eks 25) het op 'n priesterlike fantasie berus wat die tempel van Salomo na die woestyntyd terug geprojekteer het (Houtman 1980a:77-78, 80, 210-211). Soos die tempel, het dit ook oor 'n priesterdom en altaar beskik (Eks 29:44), en was dit die verskyningsplek van die Kebôd Jahwe (Num 14:10, 16:19, 17:7, 20:6). In Eksodus 33:7-11 staan die tent buite die laer en dien as ontmoetingsplek tussen Jahwe en Moses. Volgens die konteks hiervan het die Tora-openbaring voorrang bo die kultus geniet en moes die gespreksinhoud op 'n verdere afkondiging van die wet betrekking hê (Gunneweg 1988:168180). Die Tora het gestalte aan 'n wettiese godsdiens gegee. Die nomadereligie, wat tot 'n boerereligie ontwikkel het, het later plek gemaak vir 'n profetereligie en uiteindelik in 'n Tora-religie gekulmineer.

Die wettradisies het dus van 'n teofanie-openbaring tot 'n Mosaïes geopenbaarde Tora ontwikkel (Hossfeld 1982:166) wat komposisioneel in die raamwerk van 'n teofanie geplaas is (Utzschneider 1988:106). Sodoende het dit aan die wettradisies dubbele outoriteit gegee: (a) dit is aan Moses in sy priesterlike middelaarshoedanigheid geopenbaar om aan die volk bekend te maak, terwyl (b) die berg as sakramentele simbool vir God se teenwoordigheid gedien het om outoriteit aan die openbaring van die wet te verleen. Die priesterlike redaksie het hierdie realiteitskonstruksie in die Sinaikompleks opgeneem en die Tora as realiteitsperspektief van Jahwe gelegitimeer.

\section{DIE TEOLOGIESE VERBAND VAN DIE SINAIKOMPLEKS}

Die primêre karakter van die Sinaikompleks is eerder teologies as historiografies van aard. Volgens die redaksiegeskiedenis van Eksodus 19-34 vertoon die Sinaikompleks ' $n$ teologiese diversiteit wat by Sion ontstaan het, deur Horeb beweeg het en neerslag in Sinai gevind het. Hoewel Eksodus 32-34 afsonderlik 'n samehangende eenheid vorm, staan die teologiese konteks nie los van Eksodus 19-24 nie. Dit vooronderstel die selfstandige bestaan van Eksodus 19-24 en vind met verskillende motiewe daarby aansluiting. 
Sowel die deuteronomistiese as priesterlike redaksies kon met die Berg-vanGod-tradisie identifiseer en het dit ook met hul eie interpretasie uitgebrei (Eks 1924). Hierdie uitbreidings het onvermydelik tot 'n aantal herhalings gelei. Die priesterlike redaksie het dit in 'n samehangende teologiese skema geplaas waarin Israel se heilige roepingsbewussyn as 'n vereiste van die Tora gestel is (Johnstone 1987:20-24). Die stam qdš word $261 \mathrm{keer}$ in die Sinaikompleks van Eksodus 19:1 tot Numeri 10:10 aangetref. Dozeman (1989a:159-161; 1989b:87-101) verwys na die verbindingskakel as 'a spatial form technique'.

\subsection{Die Wetgewing op die Berg-van-God}

Die kombinering van die deuteronomistiese en priesterlike wetgewings lê twee ontwikkelingstadia wat uit die Berg-van-God- tradisie ontwikkel het, bloot: dit bestaan uit ' $n$ wetsafkondiging om 'n konteks vir 'n verbondsverhouding te skep in Eksodus 19-24, en 'n daaropvolgende wetsafkondiging om 'n verbondshernuwingskonteks in Eksodus 32-34 te skep. In die kanonkonstruksie hiervan word twee verbondsbeloftes aangetref, twee dekalooginterpretasies, twee verhale van die wetsopenbaring, twee weergawes van die wetstafels en twee wetgewings vir die verbondshernuwing. Sowel die deuteronomistiese as priesterlike redaksies neem die realisering van 'n spesifieke verbondsbelofte as vertrekpunt vir hul onderskeie wetgewingtradisies. Die deuteronomistiese visie beklemtoon Israel se gehoorsaamheid aan die woorde en verbond van Jahwe. Hy het die eksklusiewe reg daarop dat hulle sy persoonlike eiendom sal wees (Eks 19:5b). Hierdie visie staan in konflik met die priesterlike belofte dat Jahwe universeel oor die aarde regeer en Israel as 'n 'ryk van priesters' daarin optree (Eks 19:5b-6a). Met die saamlees van die twee beloftes, raak dit gou duidelik dat die priesterlike redaksie die sosiale eksklusiwiteit van die deu-teronomistiese visie tot 'n kwalitatiewe eksklusiwiteit gekwalifiseer het. Sodoende is die deuteronomistiese belofte herinterpreteer om die konteks vir 'n priesterlike belofte te lê.

Die samesmelting van die twee verbondsbeloftes is ook in die pariteit van die teofanietradisies en dekaloog voortgesit. Sodoende is die dekaloog gemeenskaplike besit gemaak. Die verband tussen die deuteronomistiese en priesterlike interpretasies van die teofanie is in die inleiding daarvan geskep. Hiervoor het die rede van Jahwe (Eks 19:9a, 10a; 'Jahwe het vir Moses gesê') as saambindende faktor gedien, hoewel elk van die twee redaksies sy eie afsonderlike inleiding gehad het (Dozeman 1989a:163). In die deuteronomistiese interpretasie is die teofanie met ouditiewe motiewe uitgedruk, terwyl Jahwe op 'n dik wolk gekom het ( $X / \exists$; Eks 19:8b-9a) en Moses as ' $n$ leraar van die wet voorgestel is. Die priesterlike interpretasie het daarenteen ' $n$ reiniging van die volk en afgrensing van die berg vereis voordat Jahwe 
voor almal se oë op die berg neergedaal het (ררר), terwyl Moses as middelaar vir die priesterlike wetgewing voorgestel is. Die priesterlike redaksie het die spanning tussen die twee interpretasies sodanig gekondoneer dat die dekaloog beide as direkte rede van Jahwe en as godspraak deur bemiddeling van Moses aan Israel oorgedra is.

Die priesterlike redaksie het hulle wetgewing met die verbondsboek (Eks 20:2223:33) in verband gebring deurdat dit in Eksodus 24:3-7 deel van die verbondseremonie gemaak is. Enersyds het hulle dit gedoen deur dit met nuwe materiaal uit te brei (Eks 24:1-2, 9-11), en andersyds het hulle 'n nuwe konklusie daaraan toegevoeg (Eks 24:6, 8) om die konteks vir 'n priesterlike heiliging-seremonie te skep (Durham 1978:340-344). Die heiligingsmotief baan uiteindelik die weg vir die priesterlike wetgewing in Eksodus 25-31. Die verbinding daarvan met die tent van samekoms (of tabernakel) het die Tora in 'n kultiese atmosfeer geplaas wat duidelik ooreengestem het met die aanvanklike kultiese kleur wat die berg daaraan verleen het. In Eksodus 33:7-11 sinspeel die 'Tent van Samekoms-tradisie' op die bou van die tabernakel in Eksodus 25-31 as voorvereiste vir die verbond (Moberly 1983:44-111).

\subsection{Die Wetgewing vir die verbondshernuwing}

'n Sterk band bestaan in die motief van die wet op kliptafels en die verbondshernuwing. Hierdie motief kom in 'n vierledige skema tot uitdrukking: (a) In Eksodus 24:12 ontvang Moses die opdrag om die kliptafels in ontvangs te neem, terwyl in (b) Eksodus 31:18 weer berig word dat hy die 'twee tafels van die Getuienis' geneem het. (c) In Eksodus 32:15-19 volg 'n beskrywing van die vernietiging daarvan wanneer Moses dit stukkend gooi en by implikasie die verbondsverhouding tot niet maak. (d) Ten slotte word die kliptafels wér aan Moses met die verbondsherstel uitgereik (Eks 34:1, 4, 28-29).

Die deuteronomistiese invloed blyk duidelik in Eksodus 24:12-34:35. 'n Duidelike ooreenkoms bestaan in die kliptafelmotief tussen die weergawe van die verbondshernuwing in Eksodus (Eks 24:12; 31:18; 34:1, 4, 28) en die Deuteronomiese weergawe daarvan (Deut $4: 13,5: 22 ; 9: 9-11,15 ; 10: 1,3$ ). In aansluiting hierby volg twee tekste in Deuteronomium (Deut $9: 9-19 ; 10: 1-4$ ) ook die vierledige skema vir die verbondshernuwing van Eksodus. Die feit dat die Verbondsboek reeds met die verbondsluitingseremonie in Moses se besit geplaas is (Eks 24:4; 34:27-28), en Deuteronomium die dekaloog met die twee kliptafels in verband bring, dui daarop dat die dekaloog as die inhoud van die kliptafels bedoel word en dat dit 'n deuteronomistiese motief is (Perlitt 1969:228-232; Hossfeld 1982:204-212). 
Hierdie motief is net so behou en deur die priesterlike redaksie, met die byvoeging van die 'Getuienis', as kultiese wet gelegitimeer (Eks 25:16, 21-22; 26:33-34; $27: 21 ; 30: 6,36 ; 31: 18 ; 32: 15 ; 34: 29)$. Moses se opdrag om dit in ontvangs te neem, is sodanig uitgebrei dat die kliptafels as stramien vir die hele priesterlike Tora gedien het. Volgens die priesterlike interpretasie van Eksodus 31:18 het Moses 'n nuwe kultiese wetgewing ter bevestiging van Jahwe se teenwoordigheid ontvang, wat blyk die 'tafels van die Getuienis' in Eksodus 25-31 te wees.

Hierdie dubbelsinnigheid oor die inhoud van die kliptafels is tot in die verbondshernuwingseremonie in Eksodus 34 gevoer. Eksodus 34:27-28 verwys eksplisiet na die dekaloog, terwyl die verwysing daarna in Eksodus 34:29 ontbreek wanneer Moses van die berg afklim, en volgens berig net die 'twee tafels van die Getuienis' dra. Hiervolgens blyk dit dat die berig 'n konteks vir die priesterlike wetgewing in Eksodus 35 tot Numeri 10:10 wou skep, omdat Moses dít aanvanklik met die goue kalfepisode verloor het.

Die deuteronomistiese 'kliptafel-' en die priesterlike 'tafels van Getuienis'motief het in die finale redaksionele proses as 'n gemeenskaplike wetgewing en verbondshernuwing byeengekom. Die redaktor voer dit nog verder en sluit in die voorstelling van Moses se blinkende gesig (Eks 34:29c-35) by die Kebôd Jahweteologie van Eksodus 24 aan. Op hierdie wyse is die priesterlike wetgewing vir die verbondshernuwing met 'n Kabô $d$-interpretasie afgerond.

\section{SOSIALE KONTEKS VAN DIE SINAIKOMPLEKS SE REDAKTOR}

Die konklusie dat die Sinaikompleks 'n redaksionele poging is om die deuteronomistiese en priesterlike wetgewings tot een Tora te integreer, vereis 'n ondersoek na die sosiale konteks daarvan. Die spanning tussen konkurrerende tradisies dui daarop dat die Sinaikompleks eerder op die unifiëring van strydende groepe gerig is as om die literatuur te harmoniseer.

\subsection{Priesterlike polemiek}

Die Sinaikompleks toon dat die priesterdom tot die uiterste toe geïmpliseer word. Die onderliggende motief reflekteer ' $n$ intense wedywering tussen twee priesterhuise wat in 'n stryd tussen 'n Moses- en Aäronkultus en -heiligdom tot uitdrukking gekom het. Aan die een kant was die Levitiese kringe, wat hulle priesterreg en afkoms op Moses (Schmitt 1982:575-599) teruggevoer het (Deut 33:8-11), en aan die ander kant die Sadokiete, wat hul afkoms in Aäron (Olyan 1982:177-193) gefundeer het (1 Kron 6:3-15). Hoewel Moses en Aäron in die genealogie van Levi (Eks 6:19; $1 \mathrm{Kron} \mathrm{6:3)} \mathrm{as} \mathrm{broers} \mathrm{voorgestel} \mathrm{is,} \mathrm{het} \mathrm{hulle} \mathrm{in} \mathrm{die} \mathrm{tradisies} \mathrm{tot} \mathrm{verskillende}$ priesterlike groepe ontwikkel en het die genealogieë as belangrike onderskeidingsnorm in die polemiek tussen die twee priesterlike groepe gedien. 
Hierdie polemiek is veral in die karakterrolle van Moses en Aäron en twee van sy seuns, Nadab en Abihu, tot uitdrukking gebring. Die afwesigheid van die ander twee seuns kan verklaar word as sou hulle in Aäron teenwoordig wees (Dozeman 1989a:183-191). In Eksodus 19-24 word die indruk gewek dat probeer is om Aäron op gelyke vlak met Moses te plaas deur hom (a) saam met Moses op die berg te laat verskyn (Eks 19:24; 24:1, 9), of (b) plaasvervangend in Moses se afwesigheid die volk se regsake te laat hanteer (Eks 24:14). Hierteenoor word (a) Aäron in Eksodus 32- 34 vir die volk se sonde met die goue kalf episode verantwoordelik gehou, terwyl (b) die Leviete tot 'n hoër status as die Aäron-priesters (Sadokiete) styg deurdat hulle op Moses se bevel die orde hestel het (Eks 32:25-29). Die Levitiese priesters word opvallend, in die stryd teen die afgodsdienaars (met Aäron as hoof), as Moses se bondgenote voorgestel. Hiermee is die Leviete se taak as handhawers van die Tora beklemtoon. As resultaat hiervan is hulle tot priesterdom verorden.

Die priesterlike redaksie het 'n stryd vanuit 'n monargale situasie geneem en in 'n post-eksiliese polemiek laat neerslag vind ten einde 'n belangrike en tradisionele heiligdom en kultus te verdedig. Tydens die monargale tyd het 'n stryd tussen die heiligdomme in die Noordelike ryk, wat in Dan en Bet-El deur Jerobeam I opgerig is, en dié in Juda en Jerusalem ontstaan. Dan, in die verre noorde, is met ' $n$ Levitiese priesterdom wat op Moses teruggaan geassosieer (Fohrer 1972:114-115) en Bet-El met 'n teofanie (Rowley 1981:73, 78). Die heiligdomme is enersyds deur Jerobeam I opgerig uit afguns op die heiligdom in Jerusalem, en andersyds vanweë die feit dat die koninklike heiligdomme van die konings van Juda meer prominensie geniet het. Gedurende die post-eksiliese tyd was die polemiek teen soortgelyke simbole as die goue kalf by Dan en Bet-El gerig.

Hierdie polemiek sluit goed aan by die religieuse en politieke verskille van die Persiese tyd. Nadat Kores alle ballinge gemagtig het om na hulle land van herkoms terug te keer (Esra 1:1-4), het die Judese ballinge se terugkeer in twee fases geskied. In 538 v C het \pm 50000 Jode onder leiding van Serubbabel ('n afstammeling van Dawid) en Josua ('n Sadokiet) teruggekeer (Esra 2). Hieronder was 4289 Sadokitiese priesters en 74 Leviete (Esra 2:40-70; Neh 7:43-73). Die priesterdom uit hierdie groep was grootliks van Sadokitiese afkoms en het hulself onmiddellike in die tempel van Jerusalem gevestig (Fohrer 1972:381).

$\mathrm{Na}$ tagtig jaar, in $458 \mathrm{v} \mathrm{C}$, het die tweede groep van ongeveer 10000 Jode van oorwegende Levitiese afkoms, onder leiding van Esra gevolg. Hulle was tot 'n laer priesterorde gedegradeer (Eseg 44:4-31) en het hoofsaaklik plattelandse heiligdomme in Juda bedien. Hulle was ook meer versigtig om vreemde elemente by die kultus in te dra as die priesters in Jerusalem. Met verloop van tyd het dit tot hewige konflik gelei en ook daartoe gelei dat ander groepe soos sangers, musikante en 
deurwagters in die geledere van die Leviete opgeneem is (Fohrer 1972:114-115). 'n Sterk houding van onverdraagsaamheid teenoor Kanaänitisme blyk duidelik uit Eksodus 34:11-12 en Eksodus 23:28, 32-33.

Esra was ' $n$ unieke figuur in dié sin dat hy, benewens sy priesterskap, ook skrifgeleerde was. Sy primêre opdrag was om die tempeldiens te herstel (Esra 7) en die volk van vermenging te suiwer wat gevolglik tot die wegstuur van talle vreemde vroue gelei het (Esra 9 en 10). Sy reformasie was op die geloof gebou dat Israel se krag in sy afsondering en heilige diens van Jahwe gelê het.

Hierdie tyd was ook gekenmerk deur die gespanne verhouding tussen die Samaritane in die noorde en die teruggekeerde Joodse ballinge. Aanvanklik het die Samaritane die herbou van die verwoeste tempel in Jerusalem in $536 \mathrm{v} \mathrm{C} \mathrm{belemmer}$ sodat dit eers in $520 \mathrm{v} \mathrm{C}$ voltooi kon word. Daarna het hulle weér sodanig met die heropbou van die mure van Jerusalem ingemeng sodat Nehemia eers in $445 \mathrm{v} C$ verlof van koning Artasasta van Persië kon ontvang om die mure te herbou.

\subsection{Verteenwoordigende vergadering}

Die verwysing na וְֹקָ ים 'die oudstes', dien as 'n belangrike aanwyser vir die sosiale konteks. Die woord word in twee semantiese verbande gebruik: (a) as gevolmagtigde verteenwoordigers saam met Moses voor God (Eks 24:9); en (b) as regsverteenwoordigers onder die volk (Eks 24:14).

Die tradisie in Eksodus 24:14 blyk uit sy ongekwalifiseerde getal van die oudstes 'n ouer tradisie te wees as Eksodus 24:9, en het betrekking op die instelling van 'n ondersteunende sisteem om regsake te hanteer. Terwyl Moses op die berg is, word Aäron en Hur gevolmagtig om namens hom regsake, wat deur die oudstes na hulle verwys word, te behartig. Hierdie ordening vertoon 'n hiërargiese struktuur met 'n uitvoerende hoof (Moses) as outonome gesag en 'n teokraties benoemde vergadering met gedesentraliseerde mag.

Die volmagtiging en wettiging van die oudstes verdedig 'n sosiale struktuur wat 'n ondersteunende stelsel van regsverteenwoordigers en administratiewe personeel vereis het om die uitvoerende leier by te staan. Die sosiale konteks hiervan reflekteer 'n tydperk waarin offisiële status in die koninklike hof aan die oudstes toegeken is. Reviv (1982:570-573) verbind die oorsprong van hierdie stelsel met die hervormingsinisiatief van koning Josafat (873-849 v C) waarvolgens Leviete, priesters en die familiehoofde as regters onder jurisdiksie van die hoëpriester in Jerusalem aangestel is (2 Kron 19:4-11). Gedurende die Persiese tyd is die begrip 'familiehoofde' naas 'oudstes' gebruik (Esra 4:2-3; 5:9). In die tyd van Nehemia was die begrip vir 'oudstes' reeds in onbruik gewees (Conrad 1980:128). 


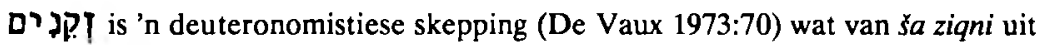
die Neo-Assiriese administratiewe gebiedsreg ontleen is. In teenstelling hiermee is $\$$ (Eks 18:13-27) in die monargale tyd gebruik. Met Tiglath-Pileser III (745727) se administratiewe hervorming is 'n hiërargie van amptenary ingestel wat direk aan die koning verantwoordelik was. In hierdie sisteem het meeste van die tradisionele familie- en gesagstrukture behoue gebly (Saggs 1984:85-86). Hierdie administratiewe stelsel het ook in die Babiloniese en Persiese tyd neerslag gevind. Ná die val van Jerusalem $(587 \vee C)$, is die Judese ballinge ook in satrapieë opgeneem, met behoud van hul eie verteenwoordigende liggaam ( 0 \\) wat die volk voor die land se gesagstrukture moes verteenwoordig. Binne die beperkinge van die kulturele en religieuse outonomie, het die Jode 'n religieuse gemeenskap gevorm wat deur hul eie Tora, en onder jurisdiksie van hul priesters, regeer is. Hierdie priesters moes in die naam van God oor verskillende sake תורות, "beslissings' (Deut 33:10), in die naam van God lewer (De Vaux 1973: 154-155).

In die tweede tradisie (Eks 24:9) word die getal van die oudstes tot sewentig gekwalifiseer. Hierdeur word die indruk gewek dat die verteenwoordigende vergadering reeds 'n bewese strukturele vorm aangeneem het, en 'n ontwikkeling van die ongekwalifiseerde getal oudstes in Eksodus 24:14 impliseer. Hul primêre funksie was nie meer net tot regspleging onder die volk beperk nie, maar het ook tot 'n kultiese verteenwoordiging voor God verskuif. Hierdie manne is met die 'gees' van Moses begunstig (Num 11:16-17) sodat hulle met die teofanie van Jahwe ook kon profeteer (Num 11:25). In Esegiël 8:10-11 word die sewentig oudstes, onder leiding van ene Jaäsanja, in Jerusalem met die invoer van afgodediens verbind.

Hoewel geen duidelike historiese lyn tussen die sewentig oudstes en die Sanhedrin gelê kan word nie, wil Joodse oorlewering die Sanhedrin as regstreekse voortsetting van die sewentig oudstes sien (Duvenhage 1977:145-146). Die ooreenkoms blyk onmiskenbaar: soos die sewentig oudstes, het die Sanhedrin ook oor die hoogste regspraak en administratiewe gesag onder die Jode beskik. Sy jurisdiksie het oor sowel die tempel as paleis gestrek. Dit het uit sewentig lede onder jurisdiksie van die hoëpriester gestaan.

Gedurende die post-eksiliese tyd het die regstelsel 'n tweeledige hiërargiese regstruktuur ontwikkel bestaande uit: (a) 'n sogenaamde 'hof van drie' met drie regslede, bygestaan deur twee Leviete, wat met minder ernstige sosiale, finansiële en religieuse sake belas was; en (b) 'n 'hof van drie-en-twintig' (klein sanhedrin) of 'n 'hof van sewentig' (groot sanhedrin) wat met sake gemoeid was wat volgens Torabe-ginsels die doodstraf vereis het (Van Tilborg 1986:52-56). Gedurende die Persiese tyd (538-400 $\vee \mathrm{C}$ ) is hierdie gesag in Jerusalem tot een-en-sewentig, bestaande uit sewentig lede en 'n hoëpriester, uitgebrei. 


\subsection{Grondslag vir 'n nuwe godsdiens}

Die Moses-karakter het ' $n$ unieke rol in die Sinaikompleks vervil. Noth (1972:162) is van mening dat die idee om Moses as wetgewer te legitimeer, 'n laat ontwikkeling in die Pentateug is. Die pre-deuteronomistiese tradisies dui Moses nie eksplisiet as wetgewer aan nie, maar beskryf hom hoogstens as 'n regter (Eks 18;). Volgens Reviv (1982:565-575) antisipeer hierdie rol van Moses die monargale funksie van die koning en reflekteer dit die tyd van Dawid, v6or die opstand van Absalom.

Onder deuteronomistiese invloed het die Moses-karakter tot 'n profetiese rol ontwikkel. Dit stem nou ooreen met Deuteronomium 18:15 en Hosea 12:14 waarvolgens 'n prominente profeet as tussenganger of leier tydens die eksodus en woestynomswerwinge tussen Jahwe en Israel sou optree (Nielsen 1982:97). Hierdie profeet is met die persoon van Moses in verband gebring.

Die priesterlike redaksie het sy karakter verder ontwikkel en 'n volwaardige priesterlike rol daaraan toegeken. Behalwe dat hy in 'n middelaarsrol en as persoonlike woordvoerder tussen Jahwe en Israel voorgestel is, het hy ook wetgewer en handhawer van die Tora geword. In Eksodus 24:14 word Aäron plaasvervangend verorden om in Moses se afwesigheid regsake te hanteer. In teenstelling met die profete, aan wie Jahwe hom in visioene, gesigte en drome openbaar het, het Hy van aangesig tot aangesig' met Moses gepraat (Eks 33:11) Daarmee het Moses en sy Tora groter voorrang bo profesie verkry. Hiermee is die vroeëre deuteronomistiese voorstelling, dat Jahwe "n profeet soos ek (Moses)' sal verwek waarna geluister moet word (Deut 18:15, 18), gerepudieer.

Die Israeliete het hul verlede dikwels met die hede gesintetiseer. Sodoende het die kultus 'n historiese kleed verkry. Aanvanklik het die afkondiging van die wet, soos uit die Psalmliteratuur blyk, oorspronklik tot die kultus behoort. Deur die toedoen van veral die deuteronomistiese en priesterlike redaksies is dit geleidelik verhistoriseer totdat dit eksklusief met Moses verbind is. Moses en sy Tora het ' $n$ belangrike norm geword om tussen ware en valse perspektiewe te onderskei. Hierdie norm het iets van die konflik tussen ware en valse profesie gedurende die tyd van die redaktor gereflekteer. Daarmee het die redaktor ook die laaste woord daaroor gespreek: die Tora het die laaste woord oor die saak.

Hoewel die verhistorisering van Moses as wetgewer volgens aanduiding reeds in die pre-eksiliese tyd, na die val van die Noordelike ryk in 722 v C, begin het, wil dit voorkom asof dit eers gedurende die eksiliese tyd werklik 'n gevestigde gedagte geraak het. Volgens Nielsen (1982:96) het die gedagte hieraan reeds teen 622 v C in sowel die tempel as koninklike paleis van Jerusalem gestalte begin kry. Ná $587 \mathrm{v}$ $\mathrm{C}$, en in besonder in die tyd van die na-eksiliese tempel ( 5 e eeu $\vee \mathrm{C}$ ), was dit reeds 'n gevestigde feit. 


\subsection{Die Priesterlike redaksie en die Esraverhaal}

Die boek Esra verwys dikwels na 'n geskrewe 'wet' (Esra 6:18; 7:6; 7:10, 12, 14, 26) waarin Esra onderlê was en wat aan die volk geleer moes word. Volgens Esra 6:18 berus die klasse-ordening van die priesters en Leviete op 'die voorskrif van die boek van Moses', terwyl die Pentateug geen sodanige indeling ken nie (Houtman 1980a: 202-204). Dit het die vraag laat ontstaan of hierdie 'wet' (a) na die Pentateug as geheel of net 'n spesifieke redaksie daarvan verwys, en (b) of die sosiale konteks van die Sinaikompleks met dié van Esra-Nehemia in verband gebring kan word.

Die karakterisering van Moses speel 'n groot rol in sowel die deuteronomistiese as priesterlike redaksies. Moses is in elkeen van die redaksies onderskeidelik as 'n leraar van die deuteronomistiese wet of bemiddelaar vir die priesterlike wet geïdealiseer. Hierdie rol van Moses is in die Sinaikompleks gekombineer. Esra is sinoniem met die karakter van Moses as 'n kombinerende faktor vir die wetgewingstradisies gekarakteriseer. Soos Moses is hy ook as 'n skrifgeleerde en priester in Esra 7:1-6 getipeer. Hierdie ooreenkoms pas goed in by 'n sosiale konteks waarin 'n sterk behoefte na 'n kompromis tussen strydende priesterlike groepe bestaan het. 'n Tweede merkwaardige ooreenkoms bestaan ook in die rol wat die verbondshernuwing as basis vir die voorlees van die wet (Neh 8-10) en die openbaring van God by die priesterlike en Deuteronomiese (die boek Deuteronomium) tradisies vereis het.

Die historiese en sosiale konteks van die middel tot laat vyfde eeu v $\mathrm{C}$ leen hom tot ' $n$ ideale milieu vir hierdie soort van kompromie tussen die verskillende ideologieë. Hierdie tyd is gekenmerk deur 'n geskiedenis van konflik wat in Juda tussen die onderskeie groepe bestaan het aangaande die bou van die tempel en dwarsdeur die vyfde eeu $v \mathrm{C}$ geduur het.

Om die Sinaikompleks en die Esra-Nehemiaverhaal, wat ten minste die afronding van die wet betref, met dieselfde sosiale konteks te verbind, vereis ' $n$ afsonderlike studie en konklusies kan nie op grond van hierdie enkele ooreenkomste gemaak word nie.

\section{KONKLUSIE}

Die kanonieke karakter van die Sinaikompleks dui daarop dat die priesterlike redaksie 'n narratiewe konteks geskep het waarin sowel die deuteronomistiese as priesterlike wetgewing tot een Tora geîntegreer is. Die redaksionele ontwikkeling daarvan is deur 'n pre-deuteronomistiese tradisie ten grondslag gelê wat aanvanklik deur 'n deuteronomistiese ontwikkelingsproses gegaan het, en uiteindelik in 'n priesterlike redaksie neerslag gevind het. 
Die gevolg hiervan was dat dit beslag aan 'n diversiteit van teologiese tradisies gegee het waarmee versekering van Jahwe se teenwoordigheid by Israel op Sinai gegee is. Hierdie tradisies is oor 'n aantal jare heen saamgevoeg en opnuut saamgebind ten einde 'n reeks van verhale op te bou wat uiteindelik aan die Sinaikomposisie beslag gegee het. Die komposisie het 'n ontwikkeling van uitbreiding en hersiening ondergaan waarin tradisies outoriteit verkry het deur met Sinai verbind te word.

Hoewel die inhoud van die Sinaikompleks in baie gevalle sodanig aangepas het om aan 'n priesterlike teologie te voldoen, is die onderskeibare simbole van Sinai en Horeb onveranderd gehandhaaf. Die interpretasie van die simbole en wetgewing is eerder saamgevoeg in 'n gemeenskaplike Tora. Sodoende het die Tora as unifiërende middel gedien in 'n konteks wat (a) 'n versekering van Jahwe se teenwoordigheid vereis het, (b) strydende groepe tot hernude eenheid moes aanspoor, en (c) die volk opnuut vir sy toekoms moes oriënteer. Die noodsaak van Jahwe se teenwoordigheid wanneer Israel van Sinai af vertrek, asook hul afhanklikheid van die verbondsverhouding met Jahwe word in Eksodus 32:11-13 beklemtoon. Ten spyte van hulle sonde word Jahwe se teenwoordigheid as onontbeerlik voorgehou. Die herstel van die verhouding en die empiriese simbool van die verbond plaas Israel se toekoms derhalwe in 'n nuwe realiteitperspektief.

Onder invloed van 'n priesterlike kanonbewussyn is die Sinaïkompleks in 'n samehangende teologiese skema geplaas waarin Israel se heilige roepingsbewussyn as 'n vereiste van die Tora gestel is. Hierdie ideologie het 'n teologiese karakter aangeneem ten einde harmonie te bewerkstellig en Israel progressief eskatologies te oriënteer. In die verwesenliking van hierdie ideaal het die berg die organisatoriese spil geword wat aan die openbaring van die Tora konteks moes verleen. Die verandering van Israel se agtergrond en realiteitsbegrip het derhalwe 'n verandering in hul verhouding met Jahwe teweeg gebring. Daarom het die redaksie enige vals persepsie probeer korrigeer. Met die beginsel dat Jahwe enige oortreding tot in die derde en vierde geslag sal straf (Eks 20:5), is 'n sosiale verantwoordelikheid op elke individu geplaas om hulle verhouding met Jahwe in 'n aanvaarbare perspektief te plaas. Die dryfveer hieragter was 'n strewe tot harmonie en eenheid.

Die streng religieuse houding van die Babiloniese diaspora en die tydperk daarna (vyfde eeu v C) word in die priesterlike redaksie tot uitdrukking gebring. Dit verhaal geskiedenis wat skerp van vroeëre tradisies verskil, maar nogtans die konsentrasie op die Mosaise tyd laat val. Al die belangrike wette en instellings is na die openbaring op Sinai teruggevoer. Hiermee is die ideaal probeer verwesenlik om 'n nuwe sosiale eenheid te skep. Hierin het die Tora gemeenskaplike besit geword om 
'n kompromis tussen die strydende groepe te bewerkstellig. Bestaande bronne is deur die Levitiese skool opgeneem en met soewereine vryheid herinterpreteer ten einde 'n nuwe sintese tussen tradisie en vernuwende teologiese refleksie te bewerkstellig.

\section{Literatuurverwysings}

Beyerlin, W 1961. Herkunft und geschichte der Sinaitradition. Tübingen: JCB Mohr. Blum, E 1990. Studien zur komposition des Pentateuch. Berlin: Walter de Gruyter. Booij, Th 1984. Mountain and theophany in the Sinai narrative. Bib 65, 1-26.

Botterweck, G J \& Ringgren, H 1978 \& 1980. Theological dictionary of the Old Testament, Vol 3 \& 4. Michigan: Eerdmans.

Childs, B S 1974. Exodus: A commentary. Londen: SCM Press. (OTL.)

Chirichigno, G C 1987. The narrative structure of Exodus 19-24. Bib 68, 457-479.

Coggins, $\mathrm{R} \mathrm{J}$ et al 1982. Israel's prophetic tradition. Cambridge: Cambridge University Press.

Cohen, $\mathbf{R}$ 1983. The mysterious MBI people: does the exodus tradition in the Bible preserve the memory of their entry into Canaan. $B A R 9 / 4,16-29$.

Conrad, J 1980. IP. Botterweck TDOT IV, 122-131.

Cross, F M 1973. Canaanite myth and Hebrew epic. Cambridge: Harvard University Press.

- 1973. The Priestly work. CMHE, 291-325.

- 1988. Reuben, first-born of Jacob. ZAW 100, 46-65.

Crüseman, F 1983. Bewährung der Freiheit: Das Thema des Dekalogs in sozialgeschichtlicher Perspektive. München: Kaiser Verlag. (KT 78.)

Davies, P R \& Gunn, D M 1984. Pentateuchal patterns: An examination of C J Labuschagne's theory. VT 34, 399-413.

Davis, D R 1982. Rebellion, presence and covenant: A study in Ex 32-34. WTJ 44, 71-87.

De Vaux, R 1973. Ancient Israel: Its life and institutions. Londen: Darton, Longman \& Todd.

Donner, $\mathbf{R}$ et al 1977. Beiträge zur alttestamentlichen Theologie: Festschrift für $W$ Zimmerli. Göttingen: Vandenhoeck \& Ruprecht.

Dozeman, T B 1989a. God on the mountain: A study of redaction, theology and canon in Exodus 19-24. Atlanta: Scholars Press.

- 1989b. Spatial form in Exodus 19:1-8a and in the larger Sinai narrative. Semeia 46, 87-101.

Durham, J I 1978. Exodus. Vol 3. Waco: Word Books. (WBC.) 
Duvenhage, S 1977. Die dékor van die Nuwe Testament: 'n Kultuur-historiese agtergrondstudie. Kaapstad: NG Kerk-uitgewers.

Fohrer, G 1972. History of Irsaelite religion. Londen: Abington.

Frank, H T \& Reed, W L 1970. Translating and understanding the Old Testament: Essays in honor of Herbert Gordon May. Nashville: Abington.

Gunneweg, A H J 1990. Das Gesetz und die Propheten. Eine Auslegung von Exodus 33:7-11; Num 11:4-12:8; Dt 31:14f; 34:10. ZAW 102, 169-180.

Hendel, R S 1989. Sacrafice as a cultural system: the ritual symbolism of Exodus 24:3-8. $Z A W 101,366-390$.

Hossfeld, F-L 1982. Der Dekalog: Seine späten Fassungen, die Originale Komposition und seine Vorstufen. Göttingen: Vandenhoeck \& Ruprecht.

— 1989. Vom Sinai zum Horeb: Stationen alttestamentlicher Glaubensgeschichte. Würzburg: Echter Verlag.

Houtman, C 1980a. Inleiding in de Pentateuch: Een bescrijving van de geschiedenis van het ondersoek naar het ontstaan en de compositie van de eerste vijf boeken van het Oude Testament met een terugblik en een evaluatie. Kampen: Kok.

Hurvitz, A 1988. Dating the Priestly source in light of the historical study of Biblical Hebrew: A century after Wellhausen. $Z A W 100,88-100$. (Supplementum.)

Johnstone, W 1987. Reactivating the Chronicles analogy in Pentateuchal studies, with special reference to the Sinai pericope in Exodus. ZAW 99, 16-37.

- 1988. The decalogue and the redaction of the Sinai pericope in Exodus. $Z A W$ 100, 361-385.

Labuschagne, C J 1982. The pattern of the divine speech formulas in the Pentateuch: The key to its literary structure. VT 32, 268-296.

- 1984a. Additional remarks on the pattern of the divine speech formulas in the Pentateuch. VT 34, 91-95.

- 1984b. Pentateuchal patterns: A reply to P R Davies and D M Gunn. VT 34, 407-413.

Mettinger, T N D 1982. The dethronement of Sabaoth: Studies in the Shem and Kabod theologies. Lund: Wallin \& Dalholm. (CBOTS 18.)

Moberly, R W L 1983. At the mountain of God: Story and theology in Exodus 32-34. Sheffield: JSOT Press.

Nicholson, E W 1974. The interpretation of Exodus 24:9-11. VT 24, 77-97.

- 1975. The antiquity of the tradition in Exodus 24:9-11. VT 25, 69-79.

- 1976. The origin of the tradition in Exodus 24:9-11. VT 26, 148-160.

- 1977. The decalogue as the direct adress of God. VT 27, 422-433.

- 1982. The covenant ritual in Exodus 24:3-8. VT 32, 74-86. 
Nielsen, E 1982. Moses and the law. VT 32, 87-98.

Noth, M 1962. Exodus. Tr by J S Bowden. Philadelphia: Westminster Press. (OTL.)

— 1972. A history of Pentateuchal traditions. Cliffs: Englewood.

Oberholzer, J P 1984. The text of Ex 20:22-23. JNSL 12, 101-105.

Olyan, S 1982. Zadok's origins and the tribal politics of David. JBL 101, 177-193.

Osumi, Y 1991. Die Kompositionsgeschichte des Bundesbuches, Exodus 20,22b-23,33. Göttingen: Vandenhoeck \& Ruprecht.

Otto, E 1988. Wandel der Rechtsbegründungen in der Gesellschaftsgeschichte des Antiken Israel: Eine rechtsgeschichte des 'Bundesbuches' Ex XX 22 - XXIII 13. Leiden: Brill. (Studia Biblica III.)

Patrick, D 1986. Old Testament law. Londen: SCM Press.

— 1989. Studying biblical law. Semeia 45, 49-65.

Perlitt, L 1969. Bundestheologie im Alten Testament. Neukirchen-VIuyn: Neukirchener Verlag.

- 1977. Sinai und Horeb, in Donner 1977:302-322.

Phillips, A 1982. Prophecy and law, in Coggins 1982:217-232.

- 1984a. A fresh look at the Sinai pericope, Part 1. VT 34, 39-52.

— 1984b. A fresh look at the Sinai pericope, Part 2. VT 34, 282-294.

Rendtorf, R 1977. Das überlieferungsgeschichtliche Problem des Pentateuch. Berlin: De Gruyter. (BZAW 147.)

Resenhöfft, W 1983. Die Quellenberichte im Josef-Sinai-Komplex (Gen 37 bis Ex 24 mit 32-34). Bern: Peter Lang.

Reviv, H 1982. The traditions concerning the inception of the legal system in Israel: significance and dating. $Z A W 94,566-575$.

Robinson, A 1982. Process analysis applied to the early traditions of Israel: a preliminary essay. $Z A W 94,549-566$.

Rowley, H H 1981. Worship in ancient Israel: Its forms and meaning. Londen: Camelot Press.

Saggs, H W F 1984. The might that was Assyria. Londen: Sedgewick.

Sailhamer, J H 1991. The Mosaic law and the theology of the Pentateuch. WTJ 53, 241-261.

— 1992. The Pentateuch as narrative: A biblical-theological commentary. Michigan: Zondervan.

Schmitt, G 1982. Der Ursprung des Levitentums. ZAW 94, 575-599.

Schmitt, W H 1983. Exodus, Sinai und Mose: Erwägungen zu Ex 1-19 und 24. Darmstadt: Wissenchaftliche Buchgesellschaft. (EdF 191.) 
Schwienhorst-Schönberger, L 1990. Das Bundesbuch (Ex 20,22-23,33) : Studien zu seiner Entstehung und Theologie. Berlin: Walter de Gruyter. (BZAW 188.)

Talmon, S 1978. הר Botterweck TDOT III, 427-447.

Toeg, A 1977. Lawgiving at Sinai: The course of development of the traditions bearing on the lawgiving at Sinai within the Pentateuch, with special emphasis on the emergence of the literary complex in Exodus xix-xxiv. Jerusalem: Magness Press.

Utzschneider, H 1988. Das Heiligtum und das Gesetz: Studien zur Bedeutung der Sinaitischen Heiligtumstexte (Ex 25-40; Lev 8-9). Göttingen: Vandenhoeck \& Ruprecht.

Van Tilborg, S 1986. The sermon on the mount as an ideological intervention: $A$ reconstruction of meaning. Assen: Van Gorcum.

Van Zyl, D C 1992. Exodus 19:3-6 and the kerygmatic perspective of the pentateuch. OTE 5, 264-271.

Vermeylen, J 1985. L'affaire du veau d'or (Ex. 32-34): Une cle pour la 'question deutéronmiste'? ZAW 97, 1-23.

Zenger, E 1971. Die Sinaitheophanie: Untersuchungen zum Jahwistischen und Elohistischen Geschichtswerk. Würzburg: Echter Verlag. 